See discussions, stats, and author profiles for this publication at:

http://www.researchgate.net/publication/262489380

\title{
PRNP polymorphisms in Tunisian sheep breeds
}

ARTICLE in LIVESTOCK SCIENCE · SEPTEMBER 2014

Impact Factor: 1.17 · DOI: 10.1016/j.livsci.2014.05.005

CITATIONS

2
READS

90

9 AUTHORS, INCLUDING:

\section{S. Kdidi}

7 PUBLICATIONS 9 CITATIONS

SEE PROFILE

\section{Gabriele Vaccari}

Istituto Superiore di Sanità

65 PUBLICATIONS $\quad \mathbf{1 , 2 9 5}$ CITATIONS

SEE PROFILE

\section{Touhami Khorchani}

Institut des Régions Arides

87 PUBLICATIONS 239 CITATIONS

SEE PROFILE 


\title{
Short communication
}

\section{PRNP polymorphisms in Tunisian sheep breeds}

\author{
S. Kdidi ${ }^{\mathrm{a}, \mathrm{b}, *}$, M.H. Yahyaoui ${ }^{\mathrm{a}}$, M. Conte ${ }^{\mathrm{c}}$, B. Chiappini ${ }^{\mathrm{c}}$, G. Zaccaria ${ }^{\mathrm{c}}$, \\ M. Ben Sassi ${ }^{\mathrm{d}}$, A. Ben Ammar El Gaaied ${ }^{\mathrm{b}}$, T. Khorchani ${ }^{\mathrm{a}}$, G. Vaccari ${ }^{\mathrm{c}}$ \\ a Livestock and Wildlife Laboratory, Arid Lands Institute, Rte. El Djorf, Km 22.5, 4119 Medenine, Tunisia \\ b Laboratory of Genetics, Immunology and Human Pathology, Faculty of Sciences, Tunis-El Manar University, Tunis 2092, Tunisia \\ ${ }^{c}$ Department of Veterinary Public Health and Food Safety, Istituto Superiore di Sanità, Viale Regina Elena, 299, 00161 Rome, Italy \\ d Office de l'Elevage et des Pâturages, 1002 Tunis, Tunisia
}

\section{A R T I C L E I N F O}

\section{Article history:}

Received 11 January 2014

Received in revised form

6 May 2014

Accepted 9 May 2014

Keywords:

PRNP

Sheep

Polymorphism

Tunisia

\begin{abstract}
A B S T R A C T
In this study, genetic variation of ovine prion protein in Tunisian sheep breeds was analysed. Sequencing of the entire coding sequence of prion protein gene (PRNP) was performed in a total of 201 samples belonging to four breeds (Barbarin, Western Thin Tail, Sicilo Sarde and Black Thibar). Five haplotypes (ARQ ARR, ARH, AHQ and VRQ) and 10 genotypes were observed based on codons 136, 154 and 171, with different frequencies among the investigated breeds. The ARQ ARR and ARH haplotypes were present in all breeds, the VRQ haplotype was observed at low frequencies in Barbarin and Western Thin Tail breeds. The ARQ and ARR haplotypes were the most common with frequencies ranging from $33.4 \%$ to $47.8 \%$ and from $26.5 \%$ to $46.5 \%$ respectively, in the different breeds. Moreover, 12 additional non-synonymous (Q101R, M112T, G127S/V, M137T, L141F, H143R, N146S, R151G, Y172D, N176K and H180Y) as well as 2 synonymous polymorphisms at codons 231 and 237 were found in the PRNP gene. Among them, the R151G polymorphism has never been described in sheep. Moreover an insertion of an octarepeat in the ARQ haplotype has been observed. These results represent the first survey on PRNP variability in Tunisian sheep and may serve as basis for the development of breeding programme to increase scrapie resistance in national sheep breeds.
\end{abstract}

(c) 2014 Elsevier B.V. All rights reserved.

\section{Introduction}

Transmissible spongiform encephalopathies are a group of fatal neurodegenerative disorders that can occur in sheep and goat (scrapie), cattle (bovine spongiform encephalopathy), or humans (Creutzfeldt-Jakob disease). The causative agent is a pathological isoform $\left(\mathrm{PrP}^{\mathrm{Sc}}\right)$ of the normal cellular prion protein $\left(\mathrm{PrP}^{\mathrm{C}}\right)$ that accumulates in brain and lymphoid tissues of the infected individuals (Prusiner,

\footnotetext{
* Corresponding author at: Livestock and Wildlife Laboratory, Arid Lands Institute, Rte. El Djorf, Km 22.5, 4119 Medenine, Tunisia.

Tel.: +21697911 581; fax: +21675633006.

E-mail address: kdidi_samia@yahoo.fr (S. Kdidi).
}

1998). In sheep, susceptibility to scrapie is influenced by polymorphisms in the amino acid sequence of the prion protein gene (PRNP) (Goldmann, 2008). The most studied polymorphisms at codons $136(\mathrm{~A} / \mathrm{V}), 154(\mathrm{R} / \mathrm{H})$ and 171 $(\mathrm{Q} / \mathrm{R} / \mathrm{H})$ of the protein are combined in five main haplotypes (expressed in single-letter amino acid code at positions 136 , 154, 171): ARQ, VRQ, AHQ, ARH and ARR. The ARR haplotype has been associated with the highest level of protection from classical scrapie, whereas VRQ ARQ AHQ and ARH with different degrees of susceptibility (Baylis et al. 2004). Additional non-synonymous mutations have been reported in several breeds, (Goldmann, 2008) mainly associated with the ARQ haplotype giving rise to at least 43 haplotypes. Nor98 or atypical scrapie, first detected in 
Norway in 1998, is a prion disease that showed distinct phenotypic characteristics compared with classical scrapie (Benestad et al., 2008). Nor98 has been identified in most European countries, in North America (Mitchell et al., 2010; Loiacono et al., 2009) and New Zealand (Kittelberger et al., 2010) with sporadic distribution. The susceptibility of sheep to this apparently spontaneous disease is also under the control of the PrP gene. Indeed the $A H Q$ and $A_{141} R Q$ haplotypes are associated with the occurrence of the disease.

In Tunisia no scrapie cases have been so far detected. It should be mentioned that although scrapie is named within the list of communicable infectious disease of animals it is not considered a priority (Dr. H. Kilani Deguiche, personal communication). Therefore, there is not a specific surveillance programme implemented in Tunisia and no central register of tested animals. These make impracticable to draw any consideration about the presence of the disease in the country.

Although scrapie has not been detected in Tunisia, it would be of interest to establish the frequencies of haplotypes that may render animals resistant to the disease. There are 7.2 million heads of sheep in Tunisia (ONAGRI, 2010 ) belonging to four different breeds: Barbarin (60.3\%), Western Thin Tail (34.6\%), Black Thibar (2.1\%) and Sicilo Sarde (0.7\%). The Barbarin and Western Thin Tail are common breeds found in Tunisia and Algeria (Iniguez, 2006). Barbarin breed originates from the Asiatic steppes (Khaldi, 1989). The Black Thibar breed resulted from crossbreeding the native Western Thin Tail and the French Merinos d'Arles breeds (Chalh et al., 2007). The SiciloSarde breed derived from a cross between the Italian Sarda and the Comisana breeds realized in late 19th century (Djemali, 2000). The Sicilo Sarde breed is the only dairy breed in the North of Africa, while the other three breeds are used for meat production contributing for more than $40 \%$ of the total red meat production (OEP, 2011).

\section{Materials and methods}

In the present work, we analysed the genetic polymorphism of PRNP in these breeds. A total of 201 blood samples were collected from Barbarin $(n=63)$, Western Thin Tail $(n=51)$, Black Thibar $(n=46)$ and Sicilo Sarde $(n=41)$. Sampling was carried out in 2011, and was obtained from different flocks located in the north, centre and south, and representing all geographic regions of the country. A total of 23 and 17 flocks were sampled from the northern departments of the country for the Black Thibar and Sicilo Sarde breeds, respectively. Barbarin and Western Thin Tail are reared throughout the whole country, and then, 49 and 29 flocks were sampled, respectively. A maximum of three samples from unrelated animals were taken per flock. Genomic DNA was extracted according to the standard protocol of phenol chloroform, and the entire PRNP coding sequence was amplified using standard conditions and F1 (5'-CAT TTA TGA CCT AGA ATG TTT ATA GCT GAT GCC A-3') and R1 (5'-TTG AAT GAA TAT TAT GTG GCC TCC TTC CAG AC-3') primers. Sequencing reactions were performed with primers T3 (5'-TTT ACG TGG GCA TTT GAT GC-3') and T4 (5'-GGC TGC AGG TAG ACA CTC C-3') using
Big Dye Terminator Cycle sequencing Kit v1.1 and an ABI PRISM 3130 apparatus (Applied Biosystems).

Deviations from Hardy-Weinberg equilibrium were evaluated using Genepop software version 4 (Raymond and Rousset, 1995) and chi-square test.

\section{Results}

The PRNP genotypes, considering the amino acids at positions 136, 154 and 171, of the four studied sheep breeds are shown on Table 1. From the fifteen genotypes commonly found in sheep, only 10 were detected in this study, ranging between 5 in Black Thibar to 8 in Sicilo Sarde. The ARR/ARQ was the most frequent genotype in Barbarin and in Black Thibar while in Western Thin Tail the common genotype was ARQ/ARQ. Two genotypes, ARQ/ ARQ and ARR/ARQ showed the highest proportions (36.6\%) in Sicilo Sarde breed. The second preponderant genotype was the ARQ/ARQ in both Barbarin and Black Thibar, the ARQ/ARR in Western Thin Tail breed and ARQ/AHQ in the Sicilo Sarde breed.

Among genotypes with the VRQ haplotype, the ARQ/ VRQ was observed only in the Western Thin Tail with low frequency (2\%) whereas the ARR/VRQ in the Barbarin (1.6\%), and it was absent in the other studied breeds. The ARR/ARR genotype, which provides a high resistance to classical scrapie, was present in all breeds, the frequencies ranged between $7.32 \%$ (Sicilo Sarde) and 23.9\% (Black Thibar). Based on Fisher's exact test, the four breeds were in Hardy-Weinberg equilibrium $(P=0.819)$ and no deviation was detected $(P>0.05)$.

Three haplotypes (ARR, ARQ and ARH) have been detected in all the studied sheep breeds (Table 2) being ARQ the most frequent in three breeds. Indeed the ARR frequency was higher than that of ARQ (46.4\% and 33.4\%, respectively) only in the Black Thibar breed.

Twelve non-synonymous polymorphisms have been detected (Q101R, M112T, G127S/V, M137T, L141F, H143R, N146S, R151G, Y172D, N176K and H180Y) in addition to two silent nucleotide substitutions $(691 \mathrm{a} \rightarrow \mathrm{c}$ and $711 \mathrm{c} \rightarrow \mathrm{g}$ ) and the insertion of an octarepeat (OR). Interestingly the R151G (cgt/ggt) polymorphism is reported here for the first time (Accession number KF830261). This codon has

Table 1

PRNP genotype frequencies (in \%) of Tunisian sheep breeds.

\begin{tabular}{lllll}
\hline \multirow{2}{*}{$\begin{array}{l}\text { PrP } \\
\text { genotypes }\end{array}$} & Breeds & & & \\
\cline { 2 - 5 } & $\begin{array}{l}\text { Barbarin } \\
(n=63)\end{array}$ & $\begin{array}{l}\text { Western Thin } \\
\text { Tail }(n=51)\end{array}$ & $\begin{array}{l}\text { Black Thibar } \\
(n=46)\end{array}$ & $\begin{array}{l}\text { Sicilo Sarde } \\
(n=41)\end{array}$ \\
\hline ARQ/ARQ & 30.2 & 43.1 & 28.3 & 36.6 \\
ARQ/AHQ & & 2 & & 9.8 \\
ARQ/ARH & 7.95 & 9.8 & 2.15 & 2.42 \\
ARQ/VRQ & & 2 & & \\
ARR/ARQ & 42.8 & 33.3 & 43.5 & 36.6 \\
ARH/ARH & & & & 2.42 \\
ARR/AHQ & & & 2.15 & 2.42 \\
ARR/ARH & 7.95 & & 23.9 & 2.42 \\
ARR/ARR & 9.5 & 9.8 & & 7.32 \\
ARR/VRQ & 1.6 & & & \\
\hline
\end{tabular}

$n=$ number of animals. 
Table 2

PRNP haplotype frequencies (in \%) of Tunisian sheep breeds.

\begin{tabular}{lccll}
\hline Haplotypes & $\begin{array}{l}\text { Barbarin } \\
(n=63)\end{array}$ & $\begin{array}{l}\text { Western Thin } \\
\text { Tail }(n=51)\end{array}$ & $\begin{array}{l}\text { Black Thibar } \\
(n=46)\end{array}$ & $\begin{array}{l}\text { Sicilo } \\
\text { Sarde } \\
(n=41)\end{array}$ \\
\hline ARR & 35.7 & 26.5 & 46.5 & 28.2 \\
VRQ & 0.7 & 1 & 0 & 0 \\
$\mathrm{AHQ}$ & 0 & 1 & 0.8 & 5.1 \\
$\mathrm{ARH}$ & 8.0 & 4.7 & 0.8 & 4.5 \\
$\mathrm{ARQ}$ & 43.5 & 41.3 & 33.4 & 47.8 \\
$\mathrm{R}_{101} \mathrm{ARQ}$ & 0.7 & 0 & 6.4 & 1.4 \\
$\mathrm{AT}_{112} \mathrm{RQ}$ & 0.7 & 2 & 1.9 & 0 \\
$\mathrm{AS}_{127} \mathrm{RQ}$ & 0 & 0 & 0.8 & 0 \\
$\mathrm{~V}_{127} \mathrm{ARQ}$ & 0.5 & 0 & 0.8 & 0 \\
$\mathrm{AT}_{137} \mathrm{RQ}$ & 0 & 0 & 0 & 3.9 \\
$\mathrm{AF}_{141} \mathrm{RQ}$ & 0.7 & 1 & 0.8 & 1.4 \\
$\mathrm{AR}_{143} \mathrm{RQ}$ & 3.0 & 5.8 & 3.4 & 0 \\
$\mathrm{AS}_{146} \mathrm{RQ}$ & 3.0 & 2 & 0 & 0 \\
$\mathrm{AG}_{151} \mathrm{RQ}$ & 0 & 0 & 0 & 1.4 \\
$\mathrm{ARQD}_{172}$ & 0.5 & 0 & 0 & 0 \\
$\mathrm{ARQK}_{176}$ & 3.0 & 11.7 & 4.4 & 6.3 \\
$\mathrm{ARQY}_{180}$ & 0 & 2 & 0 & 0 \\
$\mathrm{ARQ}^{6 \mathrm{OR}}$ & 0 & 1 & 0 & 0 \\
\hline
\end{tabular}

$n=$ Number of animals.

already been described as polymorphic: $\mathrm{R} / \mathrm{C}$ (Tranulis et al., 1999) or R/H (Acin et al., 2004) however to our knowledge the $\mathrm{G}$ variant has never been reported. An insertion of $24 \mathrm{bp}$ (GGTGGCTGGGGTCAGCCCCATGGA) in the octarepeat region between nucleotides 186 and 187 of the open reading frame has been observed in one animal of the Western Thin Tail breed. This insertion in the ARQ haplotype generates a new haplotype designed $\mathrm{ARQ}^{60 R}$ (Accession number KF830262) consisting of an additional octarepeat (PHGGGWGQ), similar to the 6 OR haplotype observed in bovine specie (McKenzie et al., 1992; Hunter et al., 1994). Although variation on the number of the octarepeats has been already observed in goat (Goldmann et al., 1998), it has never been described in sheep. The $\mathrm{V}_{127} \mathrm{ARQ}$ was showed in the Barbarin and Black Thibar breeds, while $A S_{127} R Q, A T_{137} R Q \quad A G_{151} R Q A R Q D_{172}$ and ARQY $_{180}$ haplotypes occurred only in one of the four breeds.

\section{Discussion}

The VRQ and the $\mathrm{AF}_{141} \mathrm{RQ}$ have been associated with high susceptibility to classical scrapie and Nor98 (Moum et al., 2005). These haplotypes were observed at low frequencies, the VRQ only in Barbarin and Western Thin Tail ( $0.7 \%$ and $1 \%$ respectively) while the $\mathrm{AF}_{141} \mathrm{RQ}$ in all the four breeds (with frequencies lower than 1.5\%). The AHQ haplotype, also associated with atypical scrapie susceptibility, was found in Western Thin Tail, Black Thibar and Sicilo Sarde.

The frequency of the ARR haplotype, associated with resistance to scrapie, varied between $26.5 \%$ in Western Thin Tail and $46.5 \%$ in Black Thibar. Another haplotype that has been associated with scrapie resistance (Vaccari et al., 2007, 2009a), the $\mathrm{AT}_{137} \mathrm{RQ}$ was observed only in Sicilo Sarde (3.9\%). Interestingly this haplotype has been observed in several European breeds among which the Sarda breed in Italy (Vaccari et al., 2001) from which this breed derives.
The $\mathrm{AS}_{146} \mathrm{RQ}$ haplotype is the homologous of one of the haplotypes associated to scrapie resistance in goats (for review see Vaccari et al., 2009b) and has been already observed in Asian sheep (Ün et al., 2008; Alvarez et al., 2011; Karami et al., 2011; Meydan et al., 2013). Interestingly, this haplotype has been observed in the Barbarin and Western Thin Tail, probably reflecting their breed origin. The $\mathrm{ARQK}_{176}$, haplotype has been also associated with scrapie resistance (Vaccari et al., 2007, 2009a), and it was observed in all breeds with a frequency ranging from $3.0 \%$ to $11.7 \%$.

This work represents the first report on Tunisian sheep $\operatorname{PrP}$ gene variability. Our results showed the presence of relatively high frequencies of the ARR haplotype but also of other haplotypes associated with scrapie resistance such as $\mathrm{ARQK}_{176}$. The VRQ haplotype, associated with higher susceptibility to scrapie, was observed in only two breeds with very low frequencies. Overall, our results indicated that the ovine population in Tunisia could be susceptible to both classical and atypical scrapie. These results will eventually help the development of breeding programs in Tunisia to render sheep resistant to scrapie.

\section{Conflict of interest statement}

The authors declare that there are no conflicts of interest.

\section{Acknowledgements}

The authors thank sheep owners and OEP (central office and regional directions) in Tunisia for providing blood samples and Dr Hajer Kilani Deguiche (Ministry of Agriculture, DGSV) for providing information about scrapie in Tunisia. Kdidi S. was supported by a scholarship from the Tunisian Ministry of Higher Education.

\section{References}

Acin, C., Martin-Burriel, I., Goldmann, W., Lyahyai, J., Monzon, M., Bolea, R. Smith, A., Rodellar, C., Badiola, J.J., Zaragoza, P., 2004. Prion protein gene polymorphisms in healthy and scrapie-affected sheep in Spanish sheep. J. Gen. Virol. 85, 2103-2110.

Alvarez, L., Gutierrez-Gil, B., Uzun, M., Primitivo, F.S., Arranz, J.J., 2011 Genet. Res. 99, 93-98.

Baylis, M., Chihota, C., Stevenson, E., Goldmann, W., Smith, A., Sivam, K., Gravenor, M.B., 2004. Risk of scrapie in British sheep of different prion protein genotype. J. Gen. Virol. 85, 2735-2740.

Benestad, S.L., Arsac, J.N., Goldmann, W., Noremark, M., 2008. Atypical/ Nor98 scrapie: properties of the agent, genetics, and epidemiology. Vet. Res. 39, 1-14.

Chalh, A., El Gazzah, M., Djemali, M., Chalbi, N., 2007. Genetic and phenotypic characterization of the Tunisian Noire De Thibar lambs on their growth traits. J. Biol. Sci. 7, 1347-1353.

Djemali, M., 2000. Genetic improvement objectives of sheep and goats in Tunisia. Lessons learned. Analysis and definition of the objectives in genetic improvement programmes in sheep and goats. Opt. Mediterraneennes Ser. A: Semin. Mediterraneens (France) 43, 121-127.

Goldmann, W., 2008. PrP genetics in ruminant transmissible spongiform encephalopathies. Vet. Res. 39, 30.

Goldmann, W., Chong, A., Foster, J., Hope, J., Hunter, N., 1998. The shortest known prion protein gene allele occurs in goats, has only three octapeptide repeats and is non-pathogenic. J. Gen. Virol. 79, 3173-3176. 
Hunter, N., Goldmann, W., Smith, G., Hope, J., 1994. Frequencies of PrP gene variants in healthy cattle and cattle with BSE in Scotland. Vet. Rec. 135, 400-403.

Iniguez, L., 2006. Characterization of Small Breeds in West Asia and North Africa, vols. 1 and 2. ICARDA.

Karami, M., Amirinia, C., Kashan, N.E., Amirmozafari, N., Chamani, M., Banabazi, M.H., 2011. Polymorphisms of the prion protein gene Arabi sheep breed in Iran. Afr. J. Biotechnol. 10, 15819-15822.

Khaldi, G., 1989. Barbarine sheep. In: Small ruminant in the Near East, vol III, North Africa FAO, Anim. Prod. Health 74, 96-135.

Kittelberger, R., Chaplin, M.J., Simmons, M.M., Ramirez-Villaescusa, A. McIntyre, L., MacDiarmid, S.C., Hannah, M.J., Jenner, J., Bueno, R., Bayliss, D., Black, H., Pigott, C.V., O’Keefe, J.S., 2010. Atypical scrapie/Nor98 in sheep from New Zealand. J. Vet. Diagn. Invest. 22, 863-875.

Loiacono, C.M., Thomsen, B.V., Hall, S.M., Kiupel, M., Sutton, D., O’Rourke, K, Barr, B., Anthenill, L., Keane, D., 2009. Nor98 scrapie identified in the United States. J. Vet. Diagn. Invest. 21, 454-463.

McKenzie, D.I., Cowan, C.M., Marsh, R.F., Aiken, J.M., 1992. PrP gene variability in the US cattle population. Anim. Biotechnol. 3, 309-315.

Meydan, H., Ozkan, M.M., Yildiz, M.A., Goldmann, W., 2013. Novel polymorphisms in ovine prion protein gene. Anim. Genet. 44, 588-591.

Mitchell, G.B., O'Rourke, K.I., Harrington, N.P., Soutyrine, A., Simmons, M.M., Dudas, S., Zhuang, D., Laude, H., Balachandran, A., 2010. Identification of atypical scrapie in Canadian sheep. J. Vet. Diagn. Invest. 22, 408-411.

Moum, T., Olsaker, I., Hopp, P., Moldal, T., Valheim, M., Moum, T., Benestad, L.S., 2005. Polymorphisms at codons 141 and 154 in the ovine prion protein gene are associated with scrapie Nor98 cases. J. Gen. Virol. 86, 231-235.

OEP (2011). 〈http://www.oep.nat.tn/index.php/en/donnees-sectorielles/ 41-productions>. (accessed March 8, 2014).
ONAGRI ( 2010). Annuaire de production animale. 〈http://www.onagri.tn/ index.php?option $=$ com_content\&task $=$ view\&id $=237 \&$ Itemid $=108$ (Accessed March 14, 2013).

Prusiner, S.B., 1998. Prions Proc. Nat. Acad. Sci 95, 13363-13383.

Raymond, M., Rousset, F., 1995. GENEPOP version 4, a population genetics software for exact tests and ecumenicism. J. Hered 86, 248-249.

Tranulis, M.A., Osland, A., Bratberg, B., Ulvund, M.J., 1999. Prion protein gene polymorphisms in sheep with natural scrapie and healthy controls in Norway. J. Gen. Virol. 80, 1073-1077.

Ün, C., Oztabak, K., Ozdemir, N., Akis, I., Mengib, A., 2008. Genotyping of $\operatorname{Pr} P$ gene in native Turkish sheep breeds. Small Ruminant Res. 74, 260-264.

Vaccari, G., D’Agostino, C., Nonno, R., Rosone, F., Conte, M., Di Bari, M.A., Chiappini, B., Esposito, E., De Grossi, L., Giordani, F., Marcon, S., Morelli, L., Borroni, R., Agrimi, U., 2007. Prion protein alleles showing a protective effect on the susceptibility of sheep to scrapie and bovine spongiform encephalopathy. J. Virol. 81, 7306-7309.

Vaccari, G., Panagiotidis, C.H., Acin, C., Peletto, S., Barillet, F., Acutis, P., Bossers, A., Langeveld, J., van Keulen, L., Sklaviadis, T., Badiola, J.J., Andreéoletti, O., Groschup, M.H., Agrimi, U., Foster, J., Goldmann, W., 2009b. State-of-the-art review of goat TSE in the European Union, with special emphasis on PRNP genetics and epidemiology. Vet. Res. 40, 1-18.

Vaccari, G., Petraroli, R., Agrimi, U., Eleni, C., Perfetti, M.G., Di Bari, M.A., Morelli, L., Ligios, C., Busani, L., Nonno, R., Di Guardo, G., 2001. PrP genotype in Sarda breed sheep and its relevance to scrapie. Arch. Virol. 146, 2029-2037.

Vaccari, G., Scavia, G., Sala, M., Cosseddu, G., Chiappini, B., Conte, M. Esposito, E., Lorenzetti, R., Perfetti, G., Marconi, P., Scholl, F., Barbaro, K., Bella, A., Nonno, R., Agrimi, U., 2009a. Protective effect of the ATRQ and ARQK PrP allele against classical scrapie in Sarda breed sheep. Vet. Res. $40,19-29$. 